\title{
Assessment of forest wilderness in Kalkalpen National Park
}

\author{
Simone Mayrhofer, Hanns Kirchmeir, Erich Weigand \& Erich Mayrhofer
}

Keywords: forest wilderness, protected area, national park, Austria

\section{Abstract}

In order to illustrate the state and development of forest wilderness in Kalkalpen National Park and thus also the effectiveness of national parks, we analysed various inventory data to assess the four different aspects of wilderness: naturalness, undisturbedness, undevelopedness and scale. Naturalness is proven by an analysis of hemeroby. The average hemeroby value of the park's forest is 7.2 on a scale form 1 (artificial) to 9 (natural). High density of the white-backed woodpecker population (up to 2.9 territories per $100 \mathrm{ha}$ ) and the occurrence of endangered relic beetles confirm high naturalness. Undisturbedness is proven by an increase in hemeroby development $(+0.19)$ and by the forest age from a historical viewpoint $(>50 \%$ of the forest area is older than 160 years). An evaluation of forest road density measures the quality of undevelopedness. The park's 16800 ha of forest constitute an area large and sufficient enough for ensuring functioning natural processes. Adding all these factors together, a rather high state of forest wilderness can be ascertained, which confirms the effectiveness of the national park management.
Profile

Protected area

Kalkalpen National

Park

Mountain range

Alps

Country

Austria

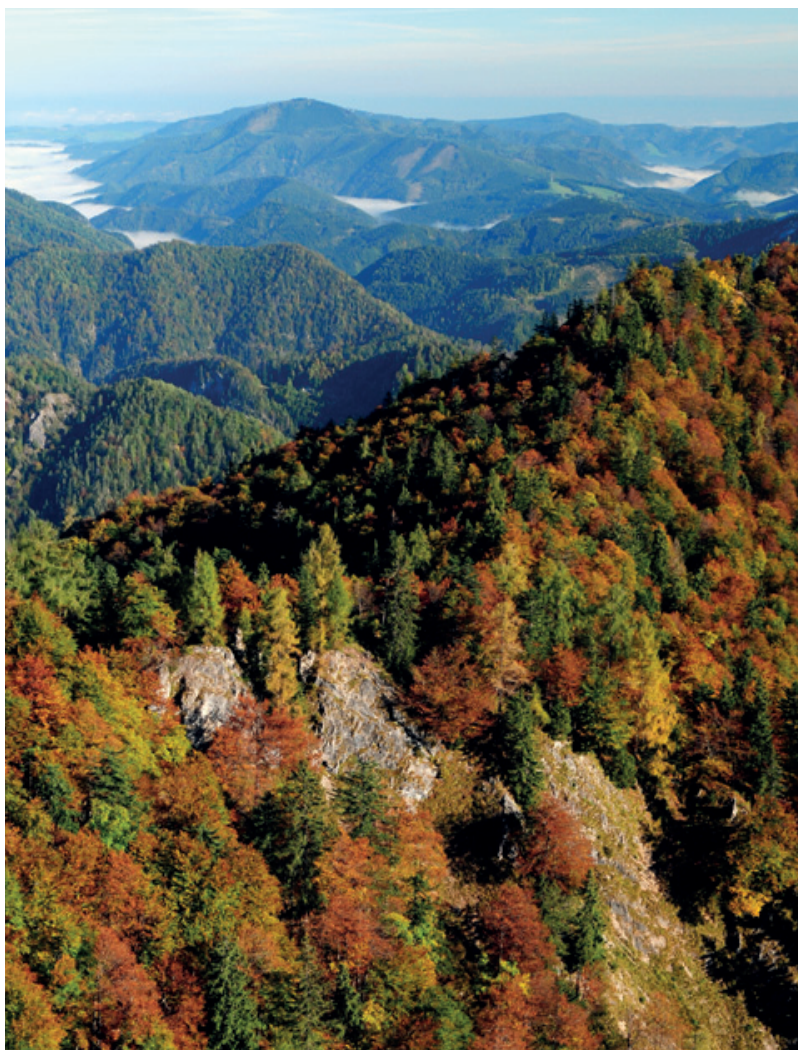

Figure 1 - An endless sea of forests in Kalkalpen NP. (C) Sieghartsleitner

\section{Introduction}

Europe has lost most of its untouched wilderness areas. Protected areas of IUCN categories I and II can significantly help to preserve the last remnants of natural ecosystems or enable a succession from managed to unmanaged nature. But is this task done effectively?
Kalkalpen National Park (NP) in Austria has defined the preservation of forest wilderness within its boundaries as a priority target. Process conservation is deemed to be the main tool for enabling the preservation and development of wilderness.

Wilderness areas - as defined by IUCN Category I or by the U.S. Wilderness Act (1964) - rarely exist in Europe (Hegyi 2008; Fisher et al. 2010). In a European context the term wilderness has to be extended to areas large enough for an effective ecological functioning of natural processes without intrusive or extractive human activity (European Commission 2013). National parks (IUCN Category II) which allow dynamic processes on a large scale (Dudley 2008) fit this definition and are particularly eligible for wilderness development. Kalkalpen NP is a candidate wilderness area category silver according to the European Wilderness Quality Standard and Audit System of the European Wilderness Society (2014).

The conservation of wilderness is an objective target that is socially desired and a main task of protected areas (Machado 2003; Mittermeier et al. 2003); however, there is no generally applicable method for recording and assessing this value.

Wilderness quality is defined by an area's remoteness and by its undisturbedness from the impacts of modern technological society (Mackey et al. 1998; Lupp et al. 2011). In this paper the following definition of wilderness from the European Guidelines on Wilderness in Natura 2000 (European Commission 2013) is used: "A wilderness is an area governed by natural processes. It is composed of native habitats and species, and large enough for the effective ecological functioning of natural processes. It is unmodified or only slightly modified and without intrusive or extractive buman activity, settlements, infrastructure or visual disturbance." 
There are several GIS-based studies which measure wilderness on the basis of wilderness quality on a regional, national or even global scale (Orsi et al. 2013; Plutzar et al. 2013; Carver et al. 2011; Fischer et al. 2010; Fritz et al. 2000; McCloskey \& Spalding 1989). Plutzar et al. (2013) assessed the wilderness quality in Austria and showed that the Austrian national parks' core zones achieve a considerably higher wilderness quality than the Austrian average. However, this study misses many results because of insufficient comparable data quality and availability, especially in the context of the well-researched NPs.

In this paper the authors attempt an assessment of the state of wilderness in Kalkalpen NP after 20 years of research and without silvicultural management. As some research results are not available as quantitative data, a descriptive approach to the assessment of forest wilderness was chosen.

Any evaluation of the effectiveness of protected areas for the conservation and development of wilderness needs to assess the four qualities of wilderness: a) naturalness, b) undisturbedness, c) undevelopedness and d) scale (EU Commission 2013).

\section{Material and methods}

\section{Study area}

Kalkalpen National Park is located in the northeastern Limestone Alps (Upper Austria) and consists of the two mountain ranges Sengsengebirge and Reichraminger Hintergebirge. Its elevation ranges from 385 to 1963 metres. The park has an area of about 20850 ha, $81 \%$ of which is covered by forest and shrub vegetation. Up to an altitude of 1450 metres, beech and spruce-fir-beech forests (Galio odorati-Fagetum Sougnez \& Thill 1959, Cyclamini Fagetum Soó (1962) 1971, Helleboro nigri-Fagetum Zukrigl 1973 s.str., Cardamine trifoliaeFagetum Oberd. 1987, Adenostyles glabrae-Fagetum Moor 1970, Saxifrago rotundifoliae-Fagetum Zukrigl 1989 s.l. (Willner 2002)) make up climax vegetation which is followed by spruce and spruce-fir forests (Adenostyles glabrae-Picetum Zukrigl 1973, Adenostyles alliariae-Picetum Zukrigl 1973). Steep slopes, weather conditions and natural hazards result in complex ongoing and highly dynamic processes with considerable effect on forest ecosystems.

The utilization history of large parts of the park, especially of some valleys in the Reichraminger Hintergebirge, has been researched meticulously (Weichenberger 1994, 1995, 1997, 1998) and can be traced back to medieval times. Other areas, such as the highest part of the park, the Sengsengebirge, lack this density of evidence. The first period with an increased demand for timber coincides with early mining. Timber logging in the current NP area began about 500 years ago and was common in the Hinterand Sengsengebirge. 42 logging dams, 16 racks, daring drifting tracks and about 100 charcoal sites bear witness to this time of intensive forest utilization

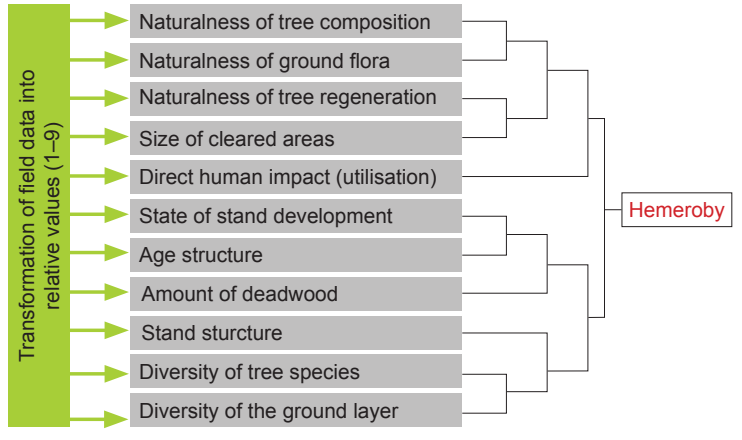

Figure 2 - The link tree shows the dichotomous aggregation of indicator values into the final hemeroby value (Grabherr et al. 1998)

(Weichenberger 1994). The current tree species composition was abandoned in favour of spruce because of its better drifting attributes. Some areas of the NP have demonstrably seen rather intensive use, others were used only once. As some of the terrain is inaccessible, it is safe to assume that not all forest areas have been used and that it was possible to preserve some areas of refuge.

\section{Naturalness}

According to the European Wilderness Guidelines, the quality naturalness includes naturalness of vegetation, naturalness of the occurring species and naturalness of the natural processes (EU Commission 2013). This quality is widely used for assessment of wilderness, but often only proxy indicators as distance to roads or settlements as well as distance from patches of artificial / modified land cover have been used (e. g. Orsi et al. 2013). This is mainly caused by the lack of spatial data on other indicators of naturalness. In this article, naturalness of vegetation is described by forest hemeroby, an inverse value of naturalness.

According to Kowarik (1988), hemeroby is "a measure for man's cultivation influence on ecosystems, whereas assessment of hemeroby level is carried out based on the extent of effects of those anthropogenic influences which affect the system's development towards a final state".

In order to measure the degree of human impact on Austrian forest ecosystems, Grabherr et al. (1998) established a specific set of indicators. The data for each of these indicators gathered from the actual situation in the field is compared to reference values describing the potential natural forest vegetation. This potential natural forest vegetation was assessed using actual vegetation and the actual stand factors (geology, soil, hydrology and climate). A classification table for each indicator was developed (Koch 1998) based on reference data for each natural forest type. Through this classification of field data, a transformation into relative values, ranging from 1-9, was made for each indicator. The indicator values are aggregated step by step in a dichotomous system and end up in one final value for each site: the hemeroby value (see Figure 2). 
Table 1 - Recorded parameters and the sizes of sample plots ( $r=$ radius) within the ecosystem monitoring in Kalkalpen NP (after Eckmüllner 1993).

\begin{tabular}{|l|l|r|}
\hline Subject & Parameters & Size of sample plot \\
\hline Site conditions & Attributes of macro- and meso-relief soil (soil type, humus type, depth...) & $\begin{array}{r}\mathrm{r}=30 \mathrm{~m} \\
\mathrm{r}=10 \mathrm{~m}\end{array}$ \\
\hline Regeneration & Single tree sampling $(<1.30 \mathrm{~m}$ ): position, height, age, game browsing... & 4 Stripes in $\mathrm{r}=10 \mathrm{~m}$ (width $40 \mathrm{~cm}$ ) \\
\hline Tree species composition & Actual / potential & $\mathrm{r}=30 \mathrm{~m}$ \\
\hline Utilization & Intensity, utilization history & $\mathrm{r}=30 \mathrm{~m}$ \\
\hline Deadwood & Quantity and quality & $\mathrm{r}=10 \mathrm{~m}$ \\
\hline Vegetation & $\begin{array}{l}\text { Vegetation sample after Braun-Blanquet } \\
\text { Actual and potential plant association } \\
\text { Structure of vegetation }\end{array}$ & $\mathrm{r}=10 \mathrm{~m}$ \\
\hline Forest yield science & Single tree sampling (> 1.30 m): position, height, diameter, vitality... & \\
\hline Stand age & Core sample of a representative tree & $\mathrm{r}=10 \mathrm{~m}$ \\
\hline
\end{tabular}

This methodology was developed for a sample of approximately 5000 plots that present a statistically sound picture of the naturalness of Austrian forest ecosystems (Grabherr et al. 1995; Grabherr et al. 1998). The field data for the Austrian wide study were collected from 1993 to 1996 and serve as reference in this study.

The ecosystem monitoring inventory of the NP was started in 1994. The monitoring programme evaluates parameters from diverse disciplines like vegetation ecology, site ecology, wildlife ecology, and forest yield science, on the basis of an inventory sampling procedure. It includes an assessment of the indicators for hemeroby.

Sampling points are placed in a $300 \mathrm{~m} \times 300 \mathrm{~m}$ grid over the entire NP area. Table 1 shows a summary of recorded parameters and the varying sizes of the sample plots (Eckmüllner et al. 1993).

Since 1994 about 1900 inventory points have been recorded. More than 400 have been re-recorded to monitor changes.

Using the same methodology of data collection allows a comparison of the naturalness of forest ecosystems within the NP with the naturalness of Austrians forests in general (Grabherr et al. 1998).

As zoological data are not considered in forest hemeroby, an analysis of the occurrence of indicator species for primeval forest ecosystems completes the picture of naturalness in Kalkalpen NP.

The number of xylobiont beetles and bird species and their specialization on dead wood is extremely high. Within the group of birds the white-backed woodpecker (Dendrocopus leucotos) - the so-called native woodpecker of primeval forests - and within the group of xylobiont beetles relic species of primeval forests were selected to assess naturalness in forest ecosystems. Müller et al. (2005) detected 115 relic beetle species of primeval forests that can be considered the strongest bio-indicators of the highest forest naturalness from a zoological point of view.

A quantitative registration of forest birds (amount of territories / breeding pairs per $100 \mathrm{ha}$ ) was conducted on study areas of 400 to 600 ha. In total, 3200 ha - almost $20 \%$ of the park's wooded area - were investigated. The method chosen was rationalized territory mapping. Territories were recorded simultaneously by three to six ornithologists. The population density can be compared to other forest regions (Weißmair 2011).

The initial recognition of primeval forest indicator beetle species was conducted by well-respected beetle experts (Eckelt \& Kahlen 2012) who investigated representative forests as well as montane riparian forest stands and forest stands that are thought to be primeval. So-called flight-interruption traps and soil traps (Barber traps) were applied. Since 2012 further investigations have been conducted by Eckelt.

The topographical conditions in the NP make for high relief energy in the area. Main dynamic influences on forest ecosystems promoting forest wilderness and a diversity of structure are avalanches, windbreaks, snow debris and bark beetle infestations. The presence of all forest development stages may be a good indicator for the naturalness of natural processes in forest ecosystems. As these data are not available for the park, the volume of dead wood and its development are used to make these dynamic processes visible and to attempt an assessment.

Eckmüllner (2013) calculated the amount of dead wood and its development on the basis of ecosystem monitoring. Dead trees were recorded by breast-height diameter and height, pieces of dead wood by estimating their volume via imagining the volume in 10 litre-buckets (one bucket equals 1/100 $\mathrm{m}^{3}$ ). Further information such as the tree species and the cause of death were recorded, too. 468 double recorded plots / subplots were used for calculation.

\section{Undisturbedness}

According to the EU Commission's definition, undisturbedness refers to an administrative, statutory or legislative measure. In other approaches the term untrammelled (U.S. Wilderness Act 1964) is also used. A wilderness area should be free from modern human control or manipulation. While existing human interventions like infrastructure and land uses are assessed in the categories of naturalness and undevelopedness, we 


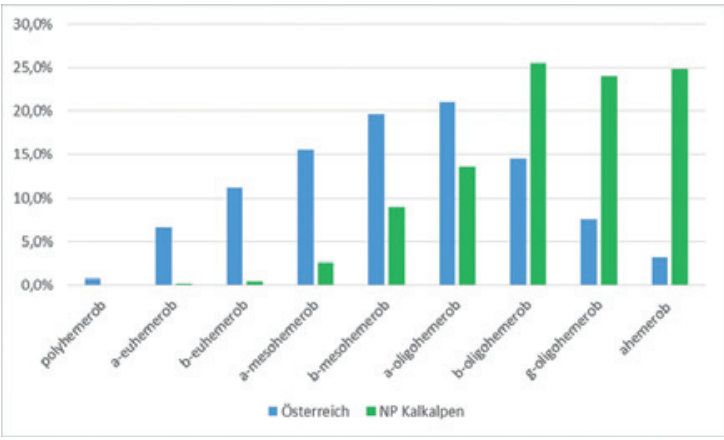

Figure 3 -Comparison of the distribution of human impact on forest ecosystems within Austria $(n=4892)$ (Grabherr et al. 1998) and in Kalkalpen NP $(n=1595)$

see the regulations on human interactions in the given area as main criteria to assess undisturbedness.

Recognition as a Ramsar and Natura 2000 site and the obligations resulting from this and from other arrangements (Alpine Convention, Convention on Biological Diversity) ensure undisturbedness. Nevertheless, the park management has to meet various demands (forest law, pasturing rights, high game stocks, etc.), and therefore established a zonation system which allows various interventions.

The zonation system and the related legal provisions do not regulate all possible disturbances, like disturbances caused by noise, light or air pollution.

Stand age has a higher explanatory power than the protection time (20 years) and therefore indicates a degree of undisturbedness from a historical point of view. Age data on forest management units were available from the park's main landowner, Austrian Federal Forests (ÖBf), and from the Archdiocese of Salzburg for $87 \%$ (14622 ha) of the wooded area of the NP. The age of representative tree layers was taken for calculation. To verify the correctness of this dataset, a correlation with tree age data from the ecosystem monitoring (point information) was calculated (correlation coefficient 0.66 ).

The development of forest hemeroby reflects an actual change of naturalness since the establishment of the NP. 383 re-recorded plots of the ecosystem monitoring were used to show the development of the degree of hemeroby.

\section{Undevelopedness}

The quality of undevelopedness can be measured by number of or distance to settlements or other human artefacts (Plutzar et al. 2013; Orsi et al. 2013; Tricker et al. 2012).

Tracks that allow motorized vehicles increase the potential for modifying the environment and are seen as human artefacts. Evaluating undevelopedness in this article is conducted by analysing length and density of the road network. All fragmenting elements are recorded and categorized by type and use, allowing detailed analysis. Marked footpaths clearly allow ac-

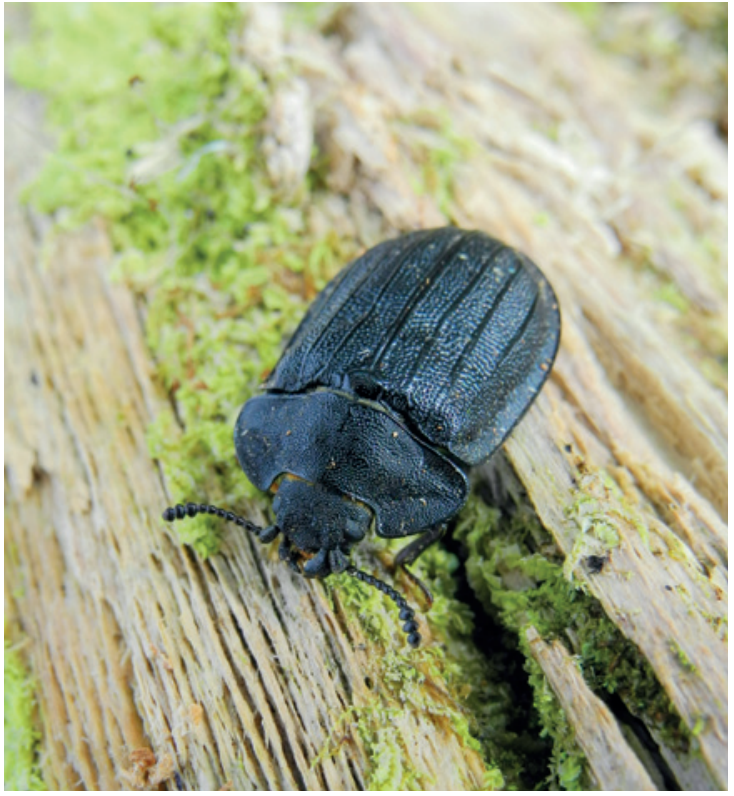

Figure 4 - Pelits grossa, a xylobiont living relic species of primeval forests. (C) E. Weigand

cess to remote areas but are excluded in the analysis because recreation and the experience of nature are deemed legitimate use of wilderness by the NP administration. While the European Wilderness Quality Standard and Audit system (European Wilderness Society 2014) sees footpaths with minimal markings in line with wilderness areas, Orsi et al. (2013) define solitude as an important factor for the perception of wilderness by visitors and have calculated the probability of meeting other visitors by length and visitor frequency on footpaths.

Aplet et al. (2000) took population density as an indicator for solitude. Kalkalpen NP only has one permanently inhabited forester's house. Therefore the distance to the road system is considered a sufficient indicator for undevelopedness.

\section{Scale}

Appropriate scale is an inevitable issue that arises within protected areas and is given by an effective functioning of natural processes (Dudley 2008). From a non-ecological viewpoint, scale is also related to anthropogenic perception of wilderness.

Fundamental for analysing scale is an evaluation of the size of forest ecosystems. The spatial dimensions of the NP and an aerial photo analysis have been used to assess these criteria. Threshold values for minimum size are given in the European Guideline on Wilderness in Natura 2000 (EU-Commission 2013).

Scanning flights were conducted in 1994 with a mean image scale of 1:17000 and 1:22 000. Tree-crown coverage was used for detailed aerial interpretation. A minimum of $46 \%$ coverage was defined as dominating occurrence of any tree species (Prüller 2009). 


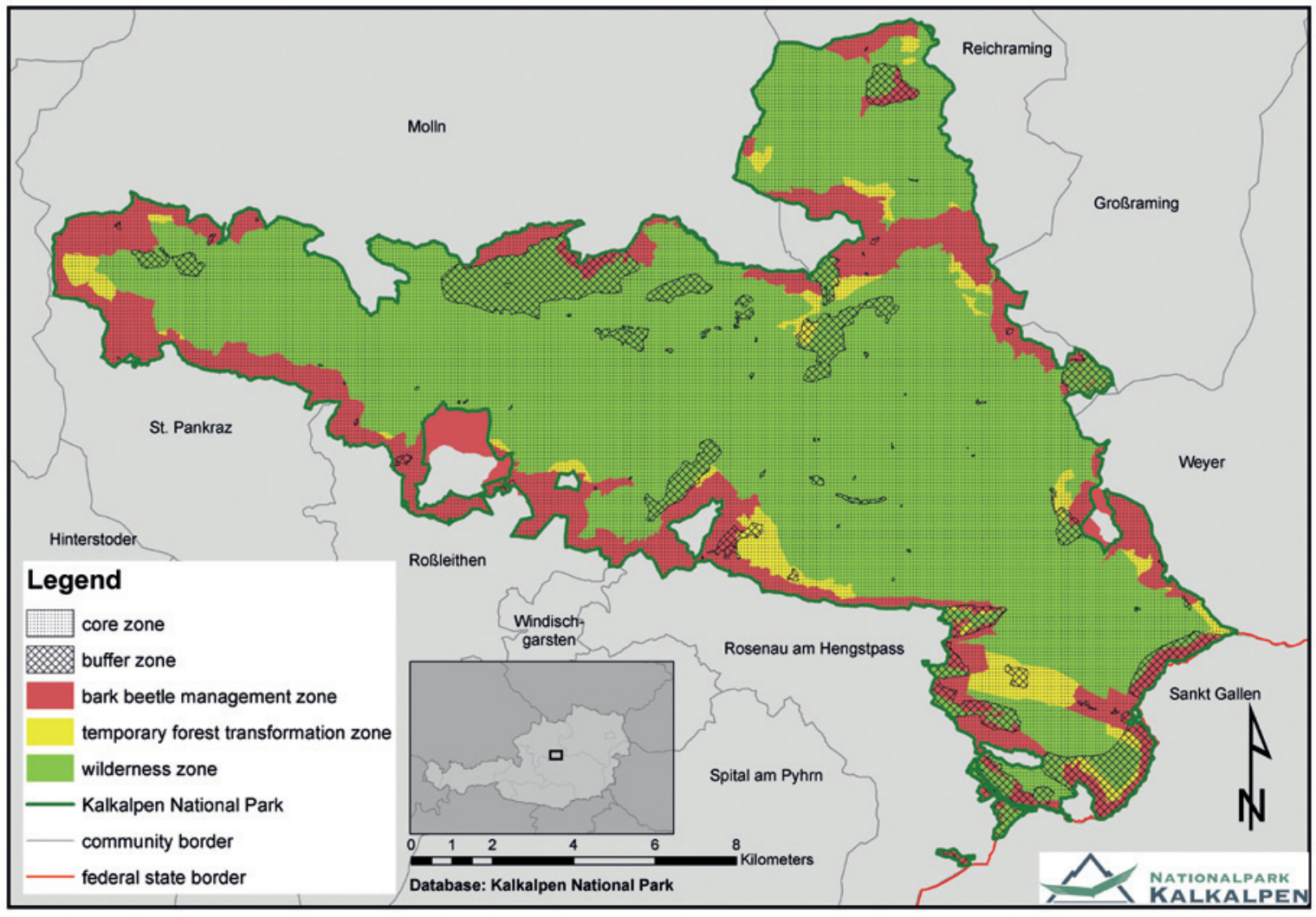

Figure 5 - Zonation system of Kalkalpen NP

\section{Results}

\section{Naturalness}

In total the data of 1595 sample plots of the ecosystem monitoring were used for the hemeroby analysis of the NP forests. Three quarters of the sample plots are ranked as semi-natural or natural. Only two sample plots $(0.09 \%)$ were assessed as artificial and 47 sample plots $(1.41 \%)$ as altered (Table 2$)$.

Comparing the results of the NP with the data gathered in a survey conducted throughout Austria (Grabherr et al. 1998) shows a significant difference in the naturalness (Figure 3).

Table 2 - Absolut and relative frequency of bemeroby values in Kalkalpen NP (first assessment of the ecosystem monitoring, $n=1595$ sample plots placed on a regular grid).

\begin{tabular}{|l|l|l|r|r|}
\hline $\begin{array}{l}\text { Hemeroby } \\
\text { value }\end{array}$ & $\begin{array}{l}\text { Hemeroby } \\
\text { classes }\end{array}$ & $\begin{array}{l}\text { Reduced } \\
\text { classes }\end{array}$ & $\begin{array}{l}\text { Absolut } \\
\text { frequency }\end{array}$ & $\begin{array}{l}\text { Relative } \\
\text { frequency }\end{array}$ \\
\hline 1 & polyhemerobic & artificial & 0 & $0.00 \%$ \\
\hline 2 & a-euhemerobic & artificial & 2 & $0.09 \%$ \\
\hline 3 & $\beta$-euhemerobic & altered & 6 & $0.19 \%$ \\
\hline 4 & a-mesohemerobic & altered & 41 & $1.22 \%$ \\
\hline 5 & $\beta$-mesohemerobic & $\begin{array}{l}\text { moderately } \\
\text { altered }\end{array}$ & 142 & $7.69 \%$ \\
\hline 6 & moderately & & \\
\hline 7 & a-oligohemerobic & altered & 218 & $14.53 \%$ \\
\hline 8 & $\beta$-oligohemerobic & semi-natural & 407 & $26.71 \%$ \\
\hline 9 & oligohemerobic & semi-natural & 382 & $23.34 \%$ \\
\hline & ahemerobic & natural & 397 & $26.24 \%$ \\
\hline
\end{tabular}

110 to 130 breeding pairs of the white-backed woodpecker live in Kalkalpen NP (Weißmair 2011). Table 3 compares population densities in different protected areas in Austria.

21 of 115 relic beetle species of primeval forests (Müller et al. 2005) were recorded in the park (Table 4) (Eckelt \& Kahlen 2012; Eckelt 2014).

A comparison of dead wood volumes of the first and second data collection indicates an increase of dead wood by $60 \%$ (Table 5). A detailed analysis shows that spruces mainly die as a result of bark beetle infestation ( $65 \%$ of all dead spruces) followed by windbreak ( $16 \%$ of all dead spruces). In comparison, beeches mainly die because of windbreaks ( $43 \%$ of all dead beeches) (Eckmüllner 2013).

\section{Undisturbedness}

The NP is subdivided into a core zone $(89 \%)$ and a buffer zone (11\%). No interference with nature and ecosystems, such as forest utilization, exercise of hunting rights or application of fertilizers and pesticides is permitted in either zone. In the core zone only activities in connection with implementing the management plan and ensuring human safety are allowed. In the buffer zone near-natural mountain pasture management, sustainable forestry and maintenance of buildings and forest tracks are also permitted.

Austrian forest law requires the removal or debarking of fallen timber because of an increased risk of insect infestation, hence the NP must practice bark beetle control. Because of an exception to the forest 
Table 3 -Comparison of the average population density (amount of territories per 100 ha) of the white-backed woodpecker (Dendrocopus leucotos) in Kalkalpen NP with other study areas in Austria.

\begin{tabular}{|l|l|r|r|}
\hline \multirow{2}{*}{ Study area } & Detailed stand information & $\begin{array}{l}\text { Population density } \\
\text { (territ. per 100 ha) }\end{array}$ & $\begin{array}{l}\text { Size of study } \\
\text { area (ha) }\end{array}$ \\
\hline \multirow{3}{*}{ Kalkalpen NP (Weißmair 2011) } & all forest area & $1-1.1$ & $16800 \mathrm{ha}$ \\
\cline { 2 - 4 } & high montane forest area & $1.5-1.87$ & $1861 \mathrm{ha}$ \\
\cline { 2 - 4 } & sub/middle montane forest area & $1.9-2.3$ & $309 \mathrm{ha}$ \\
\cline { 2 - 4 } & optimum stands & 2.8 and 2.9 & 250 and $120 \mathrm{ha}$ \\
\hline \multirow{2}{*}{$\begin{array}{l}\text { Ötscher and Dürrenstein Wilderness Area } \\
\text { (Frank \& Hochebner 2001) }\end{array}$} & all area and surrounding areas & 1.38 & $5094 \mathrm{ha}$ \\
\cline { 2 - 4 } & optimum stands & up to 2.57 & $160 \mathrm{ha}$ \\
\hline Dachstein (Weißmair \& Pühringer 2011) & - & $0.21-0.28$ & $1420 \mathrm{ha}$ \\
\hline Gesäuse NP (Teufelbauer et al. 2010) & - & 0.09 & $917 \mathrm{ha}$ \\
\hline
\end{tabular}

law, this has to be done only on $25 \%$ of the NP area (20\% bark beetle management zone and 5\% temporary forest transformation zone). Thus, $75 \%$ of the park can count as forest wilderness. The temporary forest transformation zone is meant to evolve into a forest wilderness zone over time. The zonation system is illustrated in Figure 5.

Game stock regulation is mandatory because of high stocks of game and their effects on forest regeneration. True to the concept of wilderness, this is implemented only in a designated area. 63\% of the NP area is currently called game reserve zone without any game management.

Light pollution is rather low in Kalkalpen NP. Efforts are already under way to establish a so-called starlight reserve in the region of the three protected areas Kalkalpen, Dürrenstein and Gesäuse. The situation is different for the disturbance factor noise. There are restrictions for flex wings, hang gliders and kites, but not for aeroplanes, helicopters and gliders and no minimum flyover heights have been defined. The linear distance to the nearest small airport is about $15 \mathrm{~km}$, to the nearest international airport (Linz) about $50 \mathrm{~km}$. The noise from the adjacent military firing range at Hopfing is also considerable for wild animals. Disturbances emitted by motorized vehicles are kept very low due to restrictions. However there are no studies on the effects of these noise disturbances in the NP. Tourism has to be mentioned as another source of disturbance. Visitor management is thought to ensure that $90 \%$ of the individual visitors stay within $10 \%$ of the NP area (Hees 2011).

Input of nutrients and pollutants in the protected area is quite low because of the great distances to local sources of pollution. An international monitoring site for the UN-ECE Programme Integrated Monitoring was established in the park to analyse the effects of air pollution and the consequences of climate change for ecosystems. One of the results of the long-term monitoring is a recognizable loss in biodiversity due to eutrophication and acidification (Dirnböck \& Mirtl 2009).

An analysis of hemeroby development over the last 3 to 17 years (with a 10.8 years average time gap between the assessment of the first and second data collection) reveals that naturalness is increasing within the NP (Table 6) and can therefore be interpreted as evidence for the absence of actions disturbing the forest ecosystem - at least in forest wilderness zone.

The results from the second assessment clearly reflect the different management approaches in the various zones. While active human intervention (removing infected spruces and replacing secondary spruce plantations to initiate natural forest development) is going on in the management zone (bark-beetle management zone and temporary forest transformation zone), the wilderness zone has been without direct human interference since the designation of the NP. Thus the mean hemeroby value in the management zone has not changed significantly. In total, the 383 double-assessed sample plots present a slight but distinct trend towards more natural forest ecosystems.

An evaluation of the age polygon data from the forest map shows that $51 \%$ of the forests are older than 160 years. $16 \%$ are between 121 and 160 years old; of the remaining stands $12 \%$ are between 81 and 120

Table 4 - Relic beetle species according to the list of Müller et al. (2005) recorded in Kalkalpen NP (Eckelt \& Kablen 2012; Eckelt 2014).

\begin{tabular}{|l|}
\hline Ampedus auripes (Reitter, 1895) \\
\hline Akimerus schaefferi (Laicharting, 1784) \\
\hline Bius thoracicus (Fabricius, 1792) \\
\hline Calitys scabra (Thunberg, 1784) \\
\hline Ceruchus chrysomelinus (Hochenwarth, 1785) \\
\hline Crypturgus subcribrosus (Eggers, 1933) \\
\hline Dircaea australis (Fairmaire, 1856) \\
\hline Dicerca berolinensis (Herbst, 1779) \\
\hline Dolotarsus lividus (C. Sahlberg, 1833) \\
\hline Ernobius explanatus (Mannerheim, 1843) \\
\hline Ipidia binotata (Reitter, 1875) \\
\hline Nematodes filum (Fabricius, 1801) \\
\hline Neomida haemorrhoidalis (Fabricius, 1787) \\
\hline Pediacus dermestoides (Fabricius, 1792) \\
\hline Peltis grossa (Linnaeus, 1758) \\
\hline Rhyncolus sculpturatus (Waltl, 1839) \\
\hline Rosalia alpina (Linnaeus, 1758) \\
\hline Synchita separanda (Reitter, 1882) \\
\hline Synchita undata (Guérin-Méneville, 1844) \\
\hline Tragosoma depsarium (Linnaeus, 1767) \\
\hline Xestobium austriacum (Reitter, 1890) \\
\hline
\end{tabular}




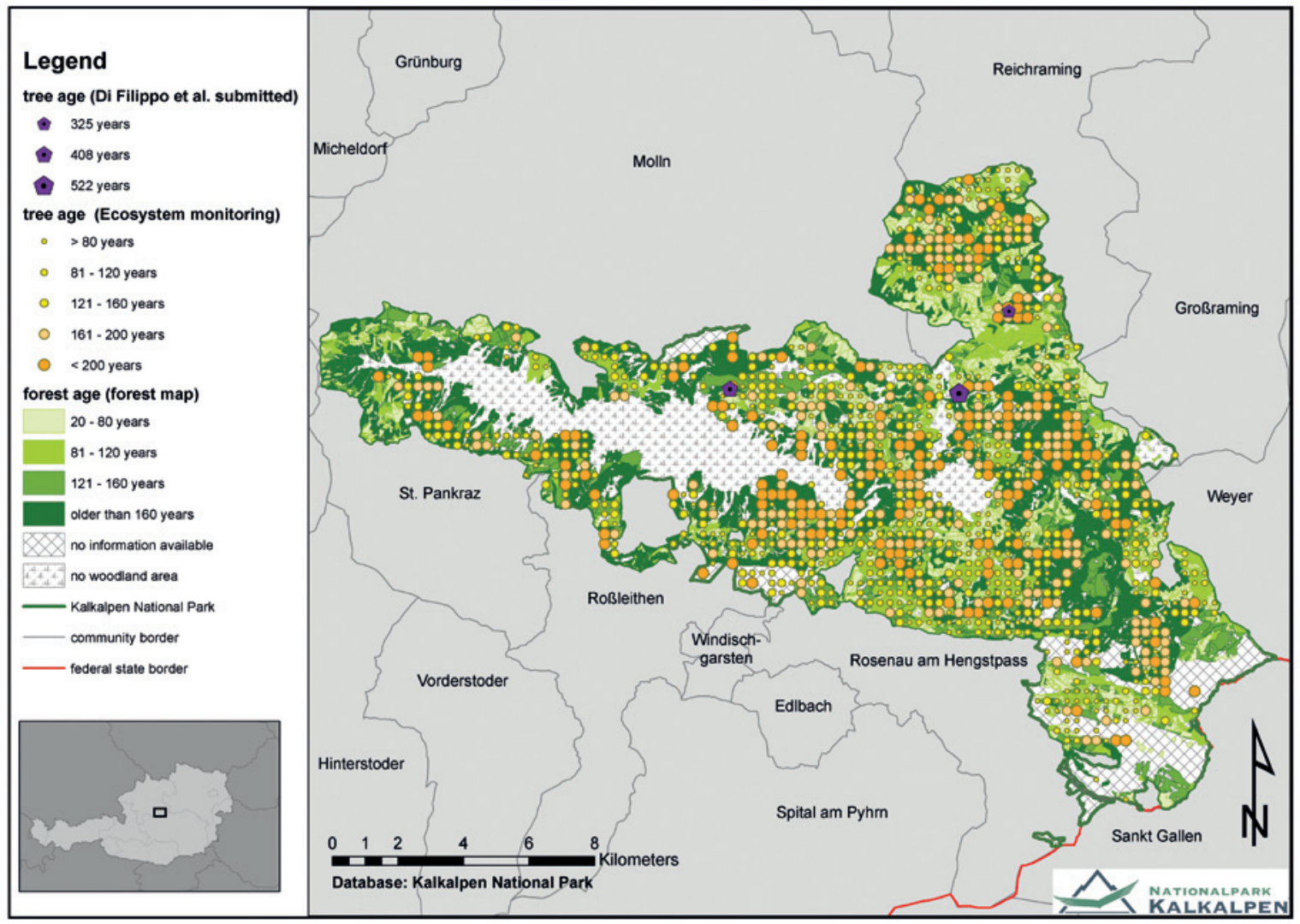

Figure 6-Available age data of forest stands/trees in Kalkalpen NP

years and 21\% between 20 and 80 years old. The high percentage of old forests demonstrates the value of the NP forests. Age data from the ecosystem monitoring suggest that many trees are considerably older than 160 years. Dendroecological research in 2012 on stands which are assumed to be primeval returned mean tree ages ranging from 250 to 304 years. A highlight was a 522-year-old beech, currently the oldest dendrochronologically dated beech tree in the Alps (Di Filippo et al. submitted). Figure 6 illustrates these age data.

\section{Undevelopedness}

Because of its silvicultural history, Kalkalpen NP has inherited a dense network of forest roads. For assessing the developedness, all maintained public and forest roads in the NP and its surrounding have been taken into account.

In general there are $198 \mathrm{~km}$ of roads used for forestry comprises, of which $105 \mathrm{~km}$ are not maintained. Forest roads are only used for management and research purposes. Other usage requires a special permission. The average Euclidian distance of a site within the NP to the closest forest road is $598 \mathrm{~m}$. About $22 \%$ of the area is more than $1000 \mathrm{~m}$ away from a road (Table 7). The total average distance of Austrian forests to the closest forest road is $55.6 \mathrm{~m}$ (ÖWI results 1992-1996). In Kalkalpen NP the average distance to forest roads is ten times larger than the Austrian average values.

\section{Scale}

Kalkalpen NP has a total area of 20850 ha, of which the core zone covers 18640 ha. Remote sensing data show $81 \%$ forest coverage. Deciduous tree coverage makes up $41 \%$ (about 8500 ha) of the area and mainly consists of beech. In the face of the intensive silvicultural management, the proportion of spruce-dominated areas seems too high at $32 \%$ and consists of primary and secondary spruce forests (about 6600 ha). Larch (Larix deciduous), pine (Pinus sylvestris) and fir (Abies alba) trees (in this order) cover the remaining 1700 ha of forest area (Prüller 2009). The forested areas are connected and not separated by zones of high human interference, such as farmland

Table 5 - Mean average volumes of dead wood in solid cubic metres per ha from first and second data collection of the ecosystem monitoring. $n=468$ sample plots placed on a regular grid (Eck-müllner 2013).

\begin{tabular}{|c|c|c|c|}
\hline & $\begin{array}{c}\text { Volume of dead wood } \\
10-20 \mathrm{~cm}\left(\mathrm{~m}^{3} / \mathrm{ha}^{1}\right)\end{array}$ & $\begin{array}{c}\text { Volume of dead wood } \\
>20 \mathrm{~cm}\left(\mathrm{~m}^{3} / \mathrm{ha}^{1}\right)\end{array}$ & $\begin{array}{l}\text { Total volume of dead } \\
\text { wood }\left(\mathrm{m}^{2} / \mathrm{ha}^{1}\right)\end{array}$ \\
\hline First data collection & 2.2 & 32.6 & 34.9 \\
\hline Second data collection & 4.3 & 51.6 & 56.0 \\
\hline
\end{tabular}


Table 6-Development of hemeroby values: Average hemeroby value of samples of the first and second assessment (on average about 12 years later) in the different management zones of Kalkalpen NP. N=383 sample plots of the ecosystem monitoring.

\begin{tabular}{|c|c|c|c|}
\hline Zone & \begin{tabular}{|l|} 
First \\
assessment
\end{tabular} & \begin{tabular}{|l|} 
Second \\
assessment
\end{tabular} & $\begin{array}{l}\text { Develop- } \\
\text { ment }\end{array}$ \\
\hline $\begin{array}{l}\text { Management zone } \\
(\mathrm{n}=74)\end{array}$ & 6.45 & 6.50 & +0.05 \\
\hline $\begin{array}{l}\text { Forest wilderness zone } \\
(\mathrm{n}=309)\end{array}$ & 7.19 & 7.43 & +0.23 \\
\hline $\begin{array}{l}\text { NP total } \\
(n=383)\end{array}$ & 7.04 & 7.23 & +0.19 \\
\hline
\end{tabular}

or settlements. This adds up to approximately 17000 ha of forest ecosystems forming a mosaic of different development stages caused by age-driven tree deaths as well as by natural hazards. This size is significantly greater than the threshold of 10000 ha listed in the Guidelines on Wilderness in Natura 2000 (EU-Commission 2013).

\section{Discussion}

\section{Naturalness}

A comparison of forest hemeroby in the NP compared with values gathered throughout Austria (Grabherr et al. 1998) highlights the natural conditions of the NP forests and the actual state of high forest wilderness. While in Austria generally only 3\% of the forest areas show no visible human impact (ahemerobic or natural), this class makes up more than $25 \%$ in the NP. Similarly, the amount of semi-natural forest sites $(\beta$ and $\gamma$-oligohemerobic) is much higher within the NP area than in the rest of Austria (Figure 3). The Austrian average hemeroby value is 5.2 ( $\beta$-mesohemerobic) against 7.2 ( $\beta$-oligohemerobic) in Kalkalpen NP. The comparison with other protected areas in Austria underlines the wilderness of the Kalkalpen forests. Results are available for Gesäuse NP (where the methodology only relates to tree species composition and stand structure) and the Viennese part of Donau-Auen NP (methodology after Grabherr et al. 1998). The high proportion of artificial stands (23\%) in Gesäuse NP (Carli \& Kreiner 2009) and (17.9\%) in the Viennese part of Donau-Auen NP (Zsak \& Illedits 2012) makes it clear that Kalkalpen NP is outstanding in forest naturalness among protected areas. About $10 \%$ of the estimated 800 to 1500 breeding pairs of the whitebacked woodpecker in Austria (Ellmauer 2005) live in Kalkalpen NP (Weißmair 2011). This extremely high and dense population of this indicator species for natural forest ecosystems is evidence of the high integrity of the NP forest. The occurrence of 21 relic primeval forest indicator beetle species is proof that these less mobile species were able to survive long silvicultural periods in refuge areas that allowed re-colonization. In the Bavarian Forest NP the existence of only 13 of these species could be verified (Bußler 2010). In the
Table 7 - Area of the NP (in \%) and its distance to the next maintained road in metres.

\begin{tabular}{|r|r|}
\hline Distance to next road & Share of area \\
\hline $0-500 \mathrm{~m}$ & $53.8 \%$ \\
\hline $501-1000 \mathrm{~m}$ & $24.7 \%$ \\
\hline $1001-1500 \mathrm{~m}$ & $14.1 \%$ \\
\hline $1501-2000 \mathrm{~m}$ & $5.7 \%$ \\
\hline$>2000 \mathrm{~m}$ & $1.7 \%$ \\
\hline
\end{tabular}

province of Upper Austria 51 relic species have been listed in total, but there is no evidence of more than half of them after the year 1950 (Eckelt 2014).

The average volume of dead wood in the park compared to the volumes in Austria generally is proof of functioning natural processes in forest ecosystems. In Kalkalpen NP, the average volume of dead wood has increased by $60 \%$ and currently amounts to about $56 \mathrm{~m}^{3} /$ ha and is comparable with other protected areas like Gesäuse NP, with a mean average of dead wood of $59.8 \mathrm{~m}^{3}$ / ha (Carli \& Kreiner 2009). Commercial forests in Austria only contain $8.1 \mathrm{~m}^{3} /$ ha of dead wood, productive protection forests an average of $11.7 \mathrm{~m}^{3}$ / ha (ÖWI results 2007-2009).

\section{Undisturbedness}

Undisturbedness as the absence of human intervention is guaranteed long-term by law. The legal definition of the various zones ensures that $49 \%$ of the NP area is free from logging, hunting / game management and other destructive human interventions. Touristic influence is present, but concentrated on forest roads and hiking paths and is governed by a visitor guidance concept. In addition, there is the educational mission of familiarizing visitors with the wilderness.

Stand age suggests that historical silvicultural influence was not equally intensive in all areas. Forest age in combination with information about forest history points to the existence of forests that were used only once. Given the intensive silvicultural management in Europe this can be interpreted as a per se value. The actual increase in naturalness confirmed via hemeroby analysis proves the effectiveness of the protected area.

\section{Undevelopedness}

The existence of forest roads is evidence of former forestry management. Nevertheless, the management demonstrates willingness to change by abandoning about half of the road kilometres. Compared with other protected areas, however, Kalkalpen NP is hardly fragmented by public roads. As the use of roads is extremely restricted, any impact of fragmentation and disturbance from forests roads is low.

\section{Scale}

Minimum areas of forest ecosystems are defined in literature to allow for the coexistence of all forest development phases. In Kalkalpen NP these minimum 
structure areas range from 50 ha for beech forests to 100 ha for alpine / montane forests. However, for these forests to be able to buffer large-scale natural disturbance events, such as avalanches, windbreak or bark beetle infestation, the defined minimum structure areas must be increased by a factor of five to ten (Parvianinen 2005).

In Kalkalpen NP the available wooded area (16800 ha) (Prüller 2009) is large enough. High viable densities of forest indicator species like the whitebacked woodpecker (Weißmair 2011) confirm this.

It must be pointed out, though, that the size of the NP will not be sufficient to conserve forest wilderness in all its different aspects (e. g. for large carnivores). Despite the high concentration of protected areas in the surrounding regions (Gesäuse NP and Dürrenstein Wilderness Area), a corridor of natural or seminatural forest vegetation to enable an exchange of genes and species does not currently exist. The Netzwerk Naturwald project initiated by the Kalkalpen NP works on establishing such a corridor that may enable the exchange and development of forest wilderness in future.

\section{Conclusion}

When adding all the results of these different aspects of naturalness, undisturbedness, undevelopedness and scale, a picture of the state of wilderness and its development can be drawn:

High naturalness and resulting high habitat quality are confirmed by results of the hemeroby analysis and by the existence / high density of primeval indicator species. Especially the existence of less mobile relic beetles validates the hypothesis of remaining refuge forests stands that enable re-colonization. While the methodology of assessing forest hemeroby based on the inventory data of the park reveals quantitative data, the zoological information on birds and beetles provides a qualitative indication of natural forest ecosystems.

The indicator quality of undisturbedness can be assessed easily by the actual regulatory framework for the various zones and can thus be classified as rather high. The strict limitations on human intervention and the exemption from the Austrian forest law as implemented in Kalkalpen NP (15628 ha) - similar to the Dürrenstein Wilderness Area (3450 ha) - can be seen as one big achievement in the development of wilderness and process conservation.

The wilderness quality undevelopedness was assessed by the existing human infrastructure, mainly through the forest road network. It is important to also include the roads outside the park to arrive at a clear picture of the degree of developedness. In this analysis, however, only maintained forest roads were assessed. Renaturation of unmaintained forest roads is not seen as a solution by the NP management because of high costs and disturbances caused by demolition work. On the contrary, abandoned roads bear witness to how quickly these anthropogenic remnants are recaptured by nature.

Assessment of the last wilderness quality, scale, rather depends on perspective and was hard to analyse quantitatively. An area may be sufficient for a group of birds and beetles, but not for large vertebrates. Focusing on forest wilderness and considering the historical and actual pressure on forest ecosystems, this quality must be rated rather highly.

The method for assessing wilderness has strengths and weaknesses. The assessment of the naturalness of dynamic processes in forest ecosystems requires a wider approach, such as checking the coexistence of all natural forest development phases. The same applies to assessing scale. The diverse quality of the data (quantitative, qualitative, age of data) must also be mentioned. The method's greatest strength is definitely the availability of quantitative data of the ecosystem monitoring as a basis for the hemeroby analysis, which was of greatest significance in this article for assessing forest wilderness. The methodology for hemeroby analysis after Grabherr et al. (1998) used in this article also increases significance. While various criteria (see Figure 2) are used by Grabherr et al. (1998), other wilderness studies assess naturalness only by the distance from human artefacts or influence (Orsi et al. 2013; Fritz et al. 2000). These factors are regarded directly in this article by the indicators for undevelopedness and indirectly by the indicators for undisturbedness.

The methodological approach gives an assessment of the wilderness in a given protected area. By applying this to other areas, a benchmark system (e.g. Orsi et al. 2013, who defined three wilderness categories for the used indicators) might be developed which helps to compare different results and to establish break values for various indicators.

Even though this benchmark is not available yet, the results from Kalkalpen NP emphasize the suitability of national parks (according to IUCN Category II) for conserving forest wilderness.

\section{References}

Aplet, G., J. Thomson \& M. Wilbert 2000. Indicators of Wildness: Using Attributes of the Land to Assess the Context of Wilderness. USDA Forest Service Proceedings RMRS-P-15, 2: 89-98.

Bußler, H. (2010). Hotspot-Gebiete xylobionter Urwaldreliktarten aus dem Reich der Käfer. LWF aktuell 76: 10-12.

Carli, A. \& D. Kreiner 2009. Waldinventur Nationalpark Gesäuse 2006-2009. Bericht im Auftrag der Nationalpark Gesäuse GmbH. Weng.

Carver, S., L. Comber, R. McMorran, S. Nutter \& J. Washtell 2011. Wildness Study in the Loch Lochmond and the Trossachs National Park. Final Report. University of Leeds. West Yorkshire. 
Di Filippo et al. (submitted). Dendroecological indices of forest naturalness in European beech (Fagus sylvatica) forests of the Alps and the Apennines.

Dirnböck, T. \& M. Mirtl 2009. Integrated Monitoring of the Effects of Airborne Nitrogen and Sulfur in the Austrian Limestone Alps. Mountain Research and Development 29(2:) 153-160.

Dudley, N. (ed.) 2008. Guidelines for Applying Protected Management Categories. IUCN. Gland, Switzerland.

Eckelt, A. \& M. Kahlen 2012. Die holzbewohnende Käferfauna des Nationalpark Kalkalpen in Oberösterreich (Coleoptera). Beitrag Naturkunde Oberösterreichs 22 3-57.

Eckelt, A. 2014. Tiroler Landesmuseum Ferdinandeum, Innsbruck. Schriftliche Mitteilung. 30.03.2014.

Eckmüllner, O. 2013. Auswertung der Wiederholungserbebungen der Naturrauminventur im Nationalpark Kalkalpen. Unpublished Study. Nationalpark Oö Kalkalpen GesmbH. Molln.

Eckmüllner, O., K. Katzensteiner, G. Koch \& F. Reimoser 1993. Naturraum-Stichprobeninventur im Nationalpark Kalkalpen. Aufnabmeschlïssel, -anweisung, -formular. Jahresberichte 1993 Verein Nationalpark Kalkalpen. Leonstein. Available at: http://wissensdatenbank. kalkalpen.at/

Ellmauer, T. (eds.) 2005. Entwicklung von Kriterien, Indikatoren und Schwellenwerten zur Beurteilung des Erhaltungszustandes der Natura 2000-Schutzgüter. Band 1: Vogelarten des Anhangs I der Vogelschutz-Richtlinie. Im Auftrag der neun österreichischen Bundesländer, des Bundesministerium für Land- und Forstwirtschaft, Umwelt und Wasserwirtschaft und der Umweltbundesamt GmbH.

European Commission (eds.) 2013. Guidelines on Wilderness in Natura 2000. Technical Report 69. Available at: http://www.eurosite.org/files/WildernessGuidelines.pdf (accessed 08/07/14)

European Wilderness Society 2014. European Wilderness Quality Standard and Audit System. Working Draft. Version 1.4. Tamsweg.

Fisher, M., S. Carver, Z. Kun, R. McMorran, K. Arrell \& G. Mitchell 2010. Review of Status and Conservation of Wild Land in Europe. Project commissioned by the Scottish Government.

Frank, G. \& T. Hochebner 2001. Erfassung der Spechte. In: Niederösterreichische Landesregierung (eds.) 2001. LIFE-Projekt „Wildnisgebiet Dürrenstein“". Forschungsbericht im Auftrag der Niederösterreichischen Landesregierung, Abteilung Naturschutz. St. Pölten: 116-148.

Grabherr, G., G. Koch, H. Kirchmeir \& K. Reiter 1995. Hemerobie österreichischer Waldökosysteme. Vorstellung eines Forschungsvorhabens im Rahmen des österreichischen Beitrages zum MAB-Programm der UNESCO. Zeitschrift Ökologie und Naturschutz 4: 105-110.

Grabherr, G., G. Koch, H. Kirchmeir \& K. Reiter 1998. Hemerobie österreichischer Waldkökosysteme. Österreichische Akademie der Wissenschaften. Innsbruck.
Hees, M. 2011. Bericht zur Umsetzung der Unternehmensziele 15 und 19. Unpublished Study. Nationalpark Oö Kalkalpen GesmbH. Molln.

Hegyi, G. 2008. Report on Wilderness in Europe. Committee on the Environment, Public Health and Food Safety. European Parliament. Session Document 2008/2210 (INI).

Koch, G. 1998. Methodik der Hemerobiebewertung. In: Grabherr, G., G. Koch, H. Kirchmeir \& K. Reiter (Hrsg.), Hemerobie österreichischer Waldökosysteme. Österreichische Akademie der Wissenschaften. Innsbruck.

Kowarik, I. 1988. Zum menschlichen Einfluß auf Flora und Vegetation. Theoretische Konzepte und ein Quantifizierungsansatz am Beispiel von Berlin (West). Landschaftsentwicklung und Umweltforschung 56: 1-280.

Lupp, G., F. Höchtl \& W. Wende 2011. Wilderness A designation for Central European landscapes? Land Use Policy 28: 594-603.

Machado, A. 2003. An index of naturalness. Journal for Nature Conservation 12: 95-110.

Mackey, B.G., R.G. Lesslie, D.B. Lindenmayer, H.A. Nix \& R.D. Incoll 1998. The Role of Wilderness in Nature Conservation. The school of Resource Management and Environmental Science. The Australian National University. Canberra.

McCloskey, J.M. \& H. Spalding 1989. A Reconnaissance-Level inventory of the amount of wilderness remaining in the world. Ambio 18(4): 221-227.

Mittermeier, R.A., C.G. Mittermeier, T.M. Brooks, J.D. Pilgrim, W.R. Konstant, G.A.B. da Fonseca \& C. Kormos 2003. Wilderness and biodiversity conservation. Proceedings of the National Academy of Sciences 100, 18: 10309-10313.

Müller, J., H. Bußler, U. Bense, H. Brustel, G. Flechtner, A. Fowles, M. Kahlen, G. Möller, H. Mühle, J. Schmidl \& P. Zabransky 2005. Urwald relic species Saproxylic beetles indicating structural qualities and habitat tradition. Waldökologie online 2: 106-113.

Orsi, F., D. Geneletti \& A. Borsdorf 2013. Mapping wildness for protected area management. A methodological approach and application to the Dolomites UNESCO World Heritage Site (Italy). Landscape and Urban Planning 120 (2013): 1-15.

ÖWI. Ergebnisse der Österreichischen Waldinventur. Available at: http://bfw.ac.at/rz/ wi.home (accessed 14/07/14)

Parviainen, J. 2005. Virgin and natural forests in the temperate zone of Europe. Forest, Snow and Landscape Research 79 (1/2): 9-18.

Plutzar, C., F. Hejjas, M. Zika \& B. Kohler 2013. Linking the wilderness continuum concept to protected areas. In: Bauch, K. (ed.), $5^{\text {th }}$ Symposium for Research in Protected Areas. Mittersill, Hohe Tauern National Park Region, Austria. Conference Volume, Part II/ 2: 587-590.

Prüller, S. 2009. Gesamtauswertung flächenhafter Elemente der Luftinterpretation im Nationalpark Kalkalpen. Unpublished Study. Nationalpark Ö̈ Kalkalpen GesmbH. Molln. 
Teufelbauer, N., M. Tiefenbach, M. Wirtitsch \& J. Pöhacker 2010. Monitoring ausgewählter Wald-Brutvogelarten im Nationalpark Gesäuse. Kartierungen 2010. Im Auftrag der Nationalparks Gesäuse GmbH. Wien.

Tricker, J., P. Landres, S. Dingman, C. Callagan, J. Stark, L. Bonstead, K. Fuhrman \& S. Carver 2012. Mapping wilderness character in Death Valley National Park. Natural Resource Report NPS/DEVA/NRR2012/503. National Park Service, Fort Collins. Colorado.

Weichenberger, J. 1994. Die Holztrift im Nationalpark Kalkalpen. Teil 1: Bestandesaufnahme. Jahresbericht. Verein Nationalpark Kalkalpen. Leonstein. Available at: http://wissensdatenbank.kalkalpen.at/

Weichenberger, J. 1995. Die Holztrift im Nationalpark Kalkalpen. Teil 2: Geschichtliche Aufarbeitung. Jahresbericht. Verein Nationalpark Kalkalpen. Leonstein. Available at: http://wissensdatenbank.kalkalpen.at/

Weichenberger, J. 1997. Der einstige Bergbau im Gebiet des Nationalparks Kalkalpen. Bericht. Nationalpark Ö̈ Kalkalpen. Molln. Available at: http:// wissensdatenbank.kalkalpen.at/

Weichenberger, J. 1998. Waldgeschichte des Jörglgrabens im Reichraminger Hintergebirge. Forschungsbericht. Nationalpark Ö̈ Kalkalpen. Molln. Available at: http:// wissensdatenbank.kalkalpen.at/

Weißmair, W. \& N. Pühringer 2011. Eulen und Spechte im Vogelschutzgebiet Dachstein (Österreich), mit besonderer Berücksichtigung der Arten des Anhang I der EU-Vogelschutzrichtlinie. Der Ornithologische Beobachter 108 (2): 81-100.

Weißmair, W. 2011. Erhebung ausgewählter Brutvogelarten des Anhang I der EU Vogelschutzrichtlinie im $\mathrm{Na}$ tionalpark Kalkalpen. Endbericht. Nationalpark Ö̈ Kalkalpen. Molln.

Wilderness Act, U.S. 1964. Public Law 88-577 (16 U.S. C 1131-1136) 88 ${ }^{\text {th }}$ Congress, Second Session.

Willner, W. 2002. Syntaxonomische Revision der südmitteleuropäischen Buchenwälder. Phytocoenologia 32: $337-453$.
Zsak, K. \& A. Illedits 2012. Hemerobiebewertung der Waldökosysteme im Wiener Anteil des Nationalpark DonauAuen. Diplomarbeit Universität Wien.

Zukrigl, K. 1973. Montane und subalpine Waldgesellschaften am Alpenostrand. Mitteilungen der forstlichen Bundes-Versuchsanstalt Wien 101: 1-387.

\section{Authors}

Simone Mayrhofer - corresponding author

is a biologist at Kalkalpen NP in Austria and responsible for various projects concerning vegetation ecology and plant diversity. Nationalpark OÖ Kalkalpen GesmbH, Nationalpark Allee 1, 4591 Molln, Austria. Email: simone.mayrhofer@kalkalpen.at

\section{Hanns Kirchmeir}

is a vegetation ecologist and has power of attorney at E.C.O. He manages forest ecology projects, is involved in protected area development in national and international projects, and lectures at the University of Klagenfurt. E.C.O. Institut für Ökologie. Kinoplatz 6, 9020 Klagenfurt. Email: kirchmeir@e-c-o.at

\section{Erich Weigand}

is a biologist currently working at Kalkalpen NP in Austria where he coordinates various research projects on animal diversity in different habitats. Nationalpark Oö Kalkalpen GesmbH, Nationalpark Allee 1, 4591 Molln, Austria. Email: erich.weigand@kalkalpen.at

\section{Erich Mayrhofer}

studied geography and meteorology and is the director of Kalkalpen NP. Since 1992 he has worked, with others, on establishing the national park. Nationalpark Ö̈ Kalkalpen GesmbH, Nationalpark Allee 1, 4591 Molln, Austria. Email: erich.mayrhofer@ kalkalpen.at 